\title{
Obituary
}

\section{Prof. J. G. Gray}

$\mathrm{E}^{\mathrm{N}}$ NGINEERS and naval architects, and medical men and women, scattered over the world, who were students at the University of Glasgow at any time in the past thirty years, will find it difficult to realise that the energetic, youthful and cheery personality of Prof. James Gordon Gray is gone from the classrooms and laboratories in which his inspiration and enthusiasm for modern applied science were available in such abundance. He lectured to two classes on November 5, and collapsed suddenly, at home, on the next afternoon.

Prof. Gray was born at Glasgow in 1876; he was the second son of the late Prof. Andrew Gray, who succeeded Lord Kelvin in 1899 to the chair of natural philosophy at the University of Glasgow. A graduate in electrical engineering, Prof. Gray joined his father's staff in 1904, and gave him much assistance in the planning of the present Natural Philosophy Institute, opened by their Majesties the King and Queen in 1907. For several years he was senior assistant in natural philosophy, and lecturer in medical physics, and his unique experience in engineering and in medical physics led in 1920 to his appointment to the new chair of applied physics, founded through the generosity of Sir John Traill Cargill, Bt., to take over the teaching of physics to all students of applied science.

At the time of his appointment, Prof. Gray was already well known for his scientific work. In his younger days he had carried out much research work on the magnetic properties of iron alloys and other alloys at liquid air temperatures and at temperatures near the Curie points of the alloys. Gradually he developed a special aptitude for designing gyroseopic apparatus to illustrate results obtained by Lord Kelvin and Prof. Andrew Gray, and finally he gave all his spare time to the theory and practice of gyroscopes. He was the inventor of motor gyroscopes and accessories, and of a large number of gyroscopic experiments that were of great educational value to his students, and of interest to thousands of others to whom he lectured all over Great Britain. His aim, frequently expressed, was to attain, by means of gyroscopes, real stability where only quasi-stability had been known before; and in this aim he was successful. During the War he co-operated with the Government in the development of appliances for use in aerial navigation and national defence, and. spent much time in the air trying out the gear he had designed. Angular momentum and the laws it obeys were very real to him, and he had an uncanny faculty for designing elaborate gyroscopic devices that functioned correctly on first trial. Stabilisers for aeroplanes and for ships, artificial horizons, automatic steering devices, apparatus for blind flying, were all developed by him. He was the pioneer inventor of the magnetic inductor compass used by Col. Lindbergh in his Atlantic flight.

Prof. Gray was a member of the Institution of Electrical Engineers, and a fellow of the Royal
Society of Edinburgh. He was joint author, with his father, of "A Treatise on Dynamics", revised by him three years ago ; and he had published numerous scientific papers. His last work, entitled "Gyroscopic Pendulums", was completed a short time ago, and is now in the press ; it consists of the Thomas Gray lectures, delivered by him this year before the Royal Society of Arts.

Prof. Gray's sudden death leaves a serious gap in the ranks of scientific workers, especially among those engaged on gyroscopic devices. He had a delightful personality, was genial in company, sympathetic to all in bereavement, and was loved by colleagues, staff and students. His students always referred to him affectionately, for his happy spirit quickly formed a bond of friendship between him and his audience, whether that audience were one of his own large university classes, or the members of one of the many scientific societies to which he lectured.

R. C. G.

\section{Dr. S. K. MukerJI}

WE regret to announce that Dr. Sushil Kurmar Mukerji, reader in botany in the University of Lucknow, and honorary secretary of the Indian Botanical Society, died on August 5.

We are indebted to an obituary by Dr. B. Sahni in Current Science of September for the following particulars of Dr. Mukerji's career. Born in 1896 at Nawgong in Central India, S. K. Mukerji was educated at Allahabad, graduated bachelor from Muir College, and master from Canning College, Lucknow. He was later appointed to the staff of the last-mentioned College, and on the inauguration of the University of Lucknow, he became demonstrator in botany, then lecturer, and, in 1927, reader.

Dr. Mukerji came into contact with many English botanists when he was preparing a thesis on the ecology of dog's mercury (Mercurialis perennis) for the degree of D.Sc. in London between 1925 and 1927. Prof. F. W. Oliver and Prof. E. J. Salisbury introduced him to a study of the soil relations of plants. He was elected a fellow of the Linnean Society, and became a member of the Sectional Committee for Botany and Forestry of the British Association at its Leeds meeting.

Since 1927, Dr. Mukerji has been studying the flora of the country round Lucknow, and also had a wide sphere of more general interests connected with the University there. At the time of his death, he was working on the fossil plants collected by the Yale University expedition to the Karakorum Mountains.

WE regret to announce the following deaths:

Prof. James Mark Baldwin, author of the "Diction. ary of Philosophy and Psychology" and other works, on November 8 , aged seventy-three years.

Prof. Karl von Linde, known for his work on refrigeration and the liquefaction of gases, on November 17, aged ninety-two years. 